Research Article

\title{
Antigenotoxic activity and antioxidant properties of organic and aqueous extracts of pequi fruit (Caryocar brasiliense Camb.) pulp
}

\author{
Ana L. Miranda-Vilela ${ }^{1}$, Inês S. Resck ${ }^{2}$ and Cesar K. Grisolia ${ }^{1}$ \\ ${ }^{1}$ Departamento de Genética e Morfologia, Instituto de Ciências Biológicas, Universidade de Brasília, \\ Brasilia, DF, Brazil. \\ ${ }^{2}$ Instituto de Química, Universidade de Brasília, Brasília, DF, Brazil.
}

\begin{abstract}
The daily consumption of natural antioxidants protects against oxidative damage caused by reactive oxygen species (ROS), including DNA damage, and can reduce the risk of cancer, atherosclerosis and other degenerative diseases. The pulp of pequi (Caryocar brasiliense Camb.) fruit, a tree native to the Brazilian savannah, contains several compounds with antioxidant properties, including carotenoids, vitamin C, phenolic compounds such as flavonoids, saponins and tannins, and essential oils. In this work, we examined the ability of organic and aqueous extracts of pequi fruit pulp to protect against the genotoxicity induced by two antineoplastic drugs, cyclophosphamide (CP) and bleomycin (BLM). Micronucleus tests with mouse bone marrow cells and single-cell gel electrophoresis (comet assay) with peripheral blood leukocytes were used to examine the effects of CP and BLM, respectively. The antioxidant activity of the extracts was assessed by measuring lipid peroxidation with the TBARS method in mouse plasma. The fruit pulp extracts had no clastogenic or genotoxic effects in the cells studied, but both extracts protected against oxidative DNA damage caused by BLM or CP, indicating an ability to inhibit chemical mutagenesis in vivo. However, the protective effect against oxidative DNA damage depended on the dose of extract used. At the doses tested, the aqueous extract enhanced lipid peroxidation in mice of both sexes, especially in males. In contrast, the organic extract enhanced lipid peroxidation only in male mice, with no significant effect in females. These results suggest that, with adequate adjustment of the dose, an organic extract of pequi fruit pulp could be a useful dietary supplement with natural antioxidant activity, at least in females.
\end{abstract}

Key words: antigenotoxic, antioxidant, Caryocar brasiliense, comet assay, micronucleus, pequi pulp extracts, reactive oxygen species, TBARS assay.

Received: October 10, 2007; Accepted: April 8, 2008.

\section{Introduction}

The pequi tree (Caryocar brasiliense Camb.), which belongs to the family Caryocaraceae, is very common in the Brazilian savannah ("cerrado"). Pequi fruit has an internal mesocarp (pequi pulp) that is used in folk medicine to treat a number of respiratory diseases (Almeida and Silva, 1994; Ramos et al., 2001). Each $100 \mathrm{~g}$ of pulp contains $20 \%-27 \%$ lipids that constitute the pulp oil, $2.2-6.0 \%$ protein, $11.6 \%$ fibers, $19.7 \%$ total carbohydrates and $225-267.9 \mathrm{kcal}$ (Almeida, 1998; Boletim Informativo UFMG n ${ }^{\circ} 1511,2005$ ). According to Almeida (1998), the fatty acid composition of pequi pulp oil consists of $51 \%$ mono-unsaturated acids, mainly oleic acid, $49 \%$ saturated oils (principally palmitic acid) and $\sim 2 \%$ polyunsaturated linoleic acid.

Pequi oil is also used in folk medicine for treating ophthalmic problems related to vitamin A deficiency, a use

Send correspondence to Cesar Koppe Grisolia. Departamento de Genética e Morfologia, Instituto de Ciências Biológicas, Universidade de Brasília, 70910-900 Brasília, DF, Brazil. E-mail: grisolia@unb.br. supported by the high content of carotenoids with provitamin A activity (Almeida and Silva, 1994; Almeida, 1998; Ramos et. al, 2001; Santos et al., 2005; Oliveira et al., 2006). In addition to $\beta$-carotene, pequi pulp contains other carotenoids, such as lycopene (Oliveira et al., 2006), $\zeta$-carotene, cryptoflavin, $\beta$-cryptoxanthine, anteraxanthine, zeaxanthine, mutatoxanthine, violanxanthine, lutein and neoxanthine (Ramos et al., 2001; Azevedo-Meleiro and Rodriguez-Amaya, 2004; Oliveira et al., 2006). Pequi pulp is also rich in vitamin C (Barbosa and Amante, 2005). W. Paula-Júnior (MSc Dissertation, Federal University of Paraná, Brazil, 2004) identified phenolic compounds, such as flavonoids, saponins and essential oils in hydroethanolic extracts of the internal mesocarp of pequi pulp, and Almeida (1998) reported a tanin content of $0.17 \mathrm{mg} / 100 \mathrm{~g}$ of pulp. All of these components of pequi pulp have antioxidant properties (Sies, 1993; Tseng et al., 2004).

Natural antioxidants in the human diet can attenuate the effects of mutagens and genotoxic carcinogens. Some antioxidants, such as vitamins $\mathrm{A}, \mathrm{C}$ and $\mathrm{E}$, minimize the 
side effects of antineoplastic drugs and can improve cancer chemotherapy. An increase in the dietary content of antioxidants through the increased ingestion of fruits and vegetables rich in these compounds can decrease the oxidation of DNA by free radicals, thereby preventing cancer and other degenerative diseases. Oxidative damage to biomolecules caused by stress is one of the major risk factors for atherosclerosis, mainly through the oxidation of low density lipoprotein (LDL) in the blood. Thus, cancer, atherosclerosis and many other degenerative diseases share a common mechanism (Kong and Lillehei, 1998; Santos and Cruz, 2001; Dusinská et al., 2003).

Some dietary antioxidants can act as adjuvants in cancer therapy because of their ability to induce apoptosis in vitro. Antioxidants also show promise in cancer therapy because of their palliative action in reducing painful side effects associated with chemotherapy (Borek, 2004). Khouri et al. (2007) showed that an aqueous extract of pequi pulp can prevent mouse bone marrow cells against chromosomal aberrations induced by bleomycin. Experiments with cultured CHO-K1 cells also showed that this aqueous extract protected cells against the clastogenic effects of cyclophosphamide.

In this study, the anticlastogenic potential of an organic extract of pequi was evaluated in mice bone marrow cells in vivo by using the micronucleus assay. The antigenotoxic effects of aqueous (AEP) and organic (OEP) extracts of pequi pulp were also evaluated by single-cell gel electrophoresis (SCGE - comet assay) in mouse peripheral blood leukocytes. The antioxidant activity of AEP and OEP on lipid peroxidation in mouse blood was assessed by the thiobarbituric acid-reactive substances (TBARS) assay.

\section{Materials and Methods}

\section{Chemicals}

Bleomycin (BLM) (CAS 011056-06-7) was obtained as Bleoxane sulphate from Bristol-Myers (São Paulo, Brazil) and cyclophosphamide (CP) (CAS 6055-19-2), sold a Genuxal, was from ASTA Medica Laboratory (São Paulo, Brazil).

\section{Plant material}

Pequi fruit was obtained in natura from vendors in Brasília, DF (Brazil) and the surrounding region. The internal mesocarp was peeled or grated to obtain the pulp, which was then packed in a covered pot and frozen to $-86^{\circ} \mathrm{C}$.

\section{Extraction procedure}

Pequi pulp was extracted by the soxhlet procedure under an argonium atmosphere using chloroform (organic extract of pequi pulp - OEP) or distilled water (aqueous extract of pequi pulp - AEP) as the solvent. After extraction, the extracts were submitted to evaporation under re- duced pressure to remove the solvents, dried at high vacuum and immediately frozen at $-86^{\circ} \mathrm{C}$.

\section{Animals}

Swiss white mice of both sexes ( 60 days old, $30 \pm 2 \mathrm{~g}$ ) obtained from the Central Animal Facility of the University of Brasília were housed in plastic cages (6 or 8/cage) at room temperature $\left(20 \pm 2{ }^{\circ} \mathrm{C}\right)$ on a $12 \mathrm{~h} \mathrm{light/dark} \mathrm{cycle}$ with lights on at $6 \mathrm{a} . \mathrm{m}$. and free access to food and water. The experimental protocols described here were approved by the institutional Ethics Committee for Animal Research (Institute of Biological Science, University of Brasília).

\section{Anticlastogenic and antigenotoxic assays}

\section{Micronucleus (MN) test}

For the MN test, only the OEP was used since the AEP has already been studied by Khouri et al. (2007). Mice of both sexes were randomly allocated to groups M1 to M12 ( $\mathrm{n}=8 \mathrm{mice} /$ group; Table 1). OEP $\left(0.5 \mathrm{~mL} \mathrm{~kg}^{-1}\right.$ or $1 \mathrm{~mL}$ $\mathrm{kg}^{-1}$ of body weight, respectively, corresponding to $15 \mu \mathrm{L}$ and $30 \mu \mathrm{L}$ of extract per mouse) was administered orally (per os, p.o.) by gavage daily for 10 days either alone or in combination with a single intraperitoneal (i.p.) injection of bleomycin diluted in $0.9 \% \mathrm{NaCl}$ or aqueous cyclophosphamide (see Table 1 for concentrations). Control mice received filtered water in place of extract and no clastogen was administered. When required, the mice were killed by cervical dislocation and slides of bone marrow cells were prepared by a standard method (Schmid, 1975). Two thousand erythrocytes were counted per mouse (1000 normochromatic erythrocytes, NCE, and 1000 polychromatic erythrocytes, PCE) and the frequency of micronuclei (MN) in PCE and NCE, and the percentage of polychromatic erythrocytes $(\% \mathrm{PCE})$ were calculated.

\section{Single-cell gel electrophoresis (SCGE) assay (comet assay)}

The SCGE assay was done essentially as for the MN test, using mice of both sexes randomly allocated to groups $\mathrm{C} 1$ to $\mathrm{C} 9$ ( $\mathrm{n}=8 \mathrm{mice} / \mathrm{group}$; Table 2 ). The comet assay was done after the MN test, using OEP $\left(0.5 \mathrm{~mL} \mathrm{hg}^{-1}\right)$ and AEP $\left(1 \mathrm{~mL} \mathrm{~kg}^{-1}\right)$ administered p.o. daily for 10 days, either alone or in combination with a single injection of bleomycin (25 mg kg$~^{-1}$, i.p.) or two injections of cyclophosphamide (at $30 \mathrm{mg} \mathrm{kg}^{-1}$, i.p. $48 \mathrm{~h}$ and $24 \mathrm{~h}$ before the mice were killed) (Table 2).

The comet assay (alkali method) proposed by Singh et al. (1988) and improved by Tice (1995) was used. Microscope slides were dipped briefly into $1.5 \%$ hot $\left(60^{\circ} \mathrm{C}\right)$ normal melting agarose prepared in phosphate-buffered saline (PBS). The slides were dried overnight at room temperature and then stored at $4{ }^{\circ} \mathrm{C}$ until used. Subsequently, freshly collected, heparinized peripheral blood $(20 \mu \mathrm{L})$ was suspended in $120 \mu \mathrm{L}$ of $0.5 \%$ low melting point agarose in 


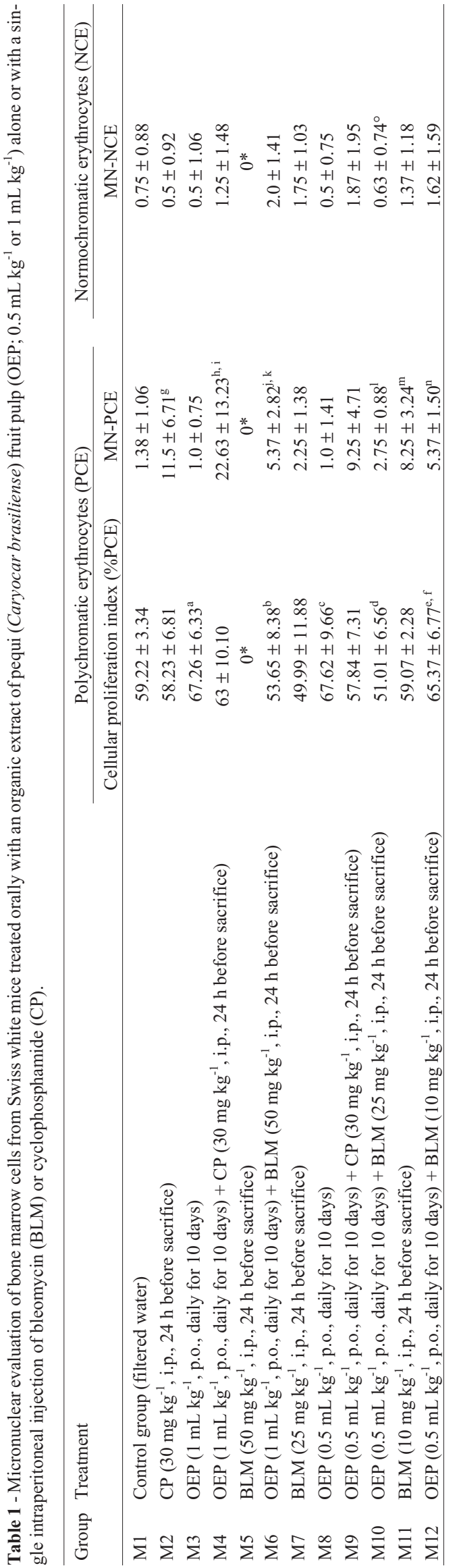

$\dot{\sum} \dot{\Sigma}$

के

S.

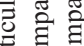

은 웅

$\circ: \circ$

둥요

개

ग्र

产安文

응요

उ.

要

官 :

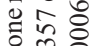

응

वี $\|$

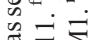

$\bar{\Sigma} \bar{\Sigma}$

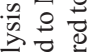

$\Rightarrow$

ठํํㄹ

两

출

* 잉

ill

की

ज्ञ

$\sum \frac{9}{9}$

莺

응

㻤

ํㅜㅇ

응

范

苞

जे

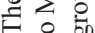

$\therefore 0$ 웅

苛芯芯

응 응

$\triangle 80$

떵요

Z 0

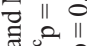

떤 늘

ㄴ.

훙용

急芯

है है

s

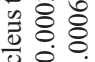

ㅋII

造

घं $\dot{\Sigma} \sum \dot{\Sigma}$

1 909

$z \overline{0}$

之 ․ㅡㄴ

过 。

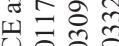

뒤휴 है

z $\mid 1 \|$
PBS (Gibco BRL) at $37^{\circ} \mathrm{C}$ and pipetted onto a microscope slide pre-coated with a layer of normal melting point agarose. This mixture was allowed to set at $4{ }^{\circ} \mathrm{C}$ for $10 \mathrm{~min}$ and the slides then immersed in a freshly prepared cold $\left(4{ }^{\circ} \mathrm{C}\right)$ lysis solution $(2.5 \mathrm{M} \mathrm{NaCl}, 100 \mathrm{mM} \mathrm{Na} 2$ EDTA, 10 $\mathrm{mM}$ Tris and $1 \%$ lauroyl sarcosine, and the $\mathrm{pH}$ adjusted to pH 10.0-10.5 with $\mathrm{NaOH} ; 1 \%$ Triton X-100 and $10 \%$ dimethyl sulfoxide were added immediately before use) at $4{ }^{\circ} \mathrm{C}$ for $1 \mathrm{~h}$. After lysis, the slides were placed in an electrophoretic tank containing $300 \mathrm{mM} \mathrm{NaOH}$ and $1 \mathrm{mM}$ EDTA, $\mathrm{pH}>13.0$ for $30 \mathrm{~min}$, and electrophoresis was then done at $25 \mathrm{~V}, 350 \mathrm{~mA}$ for $40 \mathrm{~min}$. Soon after neutralization $(3 \mathrm{x}$ 5 min in $0.4 \mathrm{M}$ Tris, $\mathrm{pH} 7.5$ at $4{ }^{\circ} \mathrm{C}$ ), the slides were stained with ethidium-bromide $(20 \mu \mathrm{g} / \mathrm{mL})$, fixed in $100 \%$ ethanol for $5 \mathrm{~min}$ and analyzed with a Zeiss Axioskop 2 fluorescence microscope (filter $510-560 \mathrm{~nm}$, barrier filter $590 \mathrm{~nm}$ ) with a final magnification of $400 x$. All of the slides were prepared and analyzed in duplicate.

SCGE analysis: One hundred comets on each slide were scored visually and assigned to classes $0-4$, as proposed by Collins (1995). Nucleoids with bright heads and no apparent tails were assigned to category 0 , whereas comets with very small heads and long, diffuse tails were assigned to category 4 . Comets with intermediate features between classes 0 and 4 were assigned to classes 1, 2 and 3 . The number of comets in each category was counted and the average DNA damage (DD, expressed in arbitrary units, a.u.) was calculated according to Jalonszynski et al. (1997), as follows:

$$
D D=\frac{n_{1}+2 n_{2}+3 n_{3}+4 n_{4}}{\frac{\sum}{100}}
$$

where $n_{1}-n_{4}=$ the number of comets in categories $1-4$, and $\Sigma=$ the sum of all comets, including category 0 .

\section{In vivo antioxidant assay: thiobarbituric acid-reactive} substances (TBARS) test

For the TBARS test, six groups (T1-T6) of eight mice each (4 males, 4 females) were used, as follows:

T1: Female control group (filtered water only, by gavage, daily, for 10 days)

T2: Male control group (filtered water only, by gavage, daily, for 10 days)

T3: Females treated with OEP $\left(0.5 \mathrm{~mL} \mathrm{~kg}^{-1}\right.$, by gavage, daily for 10 days)

T4: Males treated with OEP $\left(0.5 \mathrm{~mL} \mathrm{~kg}^{-1}\right.$, by gavage, daily for 10 days)

T5: Females treated with AEP $\left(1.0 \mathrm{~mL} \mathrm{~kg}^{-1}\right.$, by gavage, daily for 10 days)

T6: Males treated with AEP $\left(1.0 \mathrm{~mL} \mathrm{~kg}^{-1}\right.$, by gavage, daily for 10 days)

The TBARS assay was done according to Wasowicz et al. (1993), with slight modification. The TBA solution 
Table 2 - Comet assay of peripheral leukocytes from Swiss white mice treated orally with an organic $\left(\mathrm{OEP}, 0.5 \mathrm{~mL} \mathrm{~kg}^{-1}\right)$ or aqueous $\left(\mathrm{AEP}, 1 \mathrm{~mL} \mathrm{~kg}{ }^{-1}\right)$ extract of pequi (Caryocar brasiliense) fruit pulp, alone or with bleomycin (BLM, single injection, i.p.) or cyclophosphamide (CP, two injections, i.p.).

\begin{tabular}{|c|c|c|c|c|c|c|c|}
\hline \multirow[t]{2}{*}{ Group } & \multirow[t]{2}{*}{ Treatment } & \multicolumn{5}{|c|}{ Comet classes (mean $\pm \mathrm{SD})$} & \multirow[t]{2}{*}{ Mean \pm SD of DD } \\
\hline & & 0 & 1 & 2 & 3 & 4 & \\
\hline $\mathrm{C} 1$ & Control group (filtered water) & $11.62 \pm 5.34$ & $61.25 \pm 18.7$ & $22 \pm 10.4$ & $4.75 \pm 5.6$ & $0.38 \pm 0.52$ & $121 \pm 20.89$ \\
\hline $\mathrm{C} 2$ & $\begin{array}{l}\mathrm{CP}\left(30 \mathrm{mg} \mathrm{kg}^{-1} \text {, i.p., } 48 \text { and } 24 \mathrm{~h} \text { before sac- }\right. \\
\text { rifice })\end{array}$ & $3.63 \pm 2.88$ & $6.63 \pm 4.84$ & $10.38 \pm 6.80$ & $31.88 \pm 12.45$ & $47.63 \pm 13.75$ & $313.5 \pm 26.91^{\mathrm{a}}$ \\
\hline $\mathrm{C} 3$ & OEP $\left(0.5 \mathrm{~mL} \mathrm{~kg}^{-1}\right.$, p.o., daily for 10 days $)$ & $12 \pm 7.98$ & $46 \pm 20.78$ & $26.29 \pm 8.03$ & $5.57 \pm 8.55$ & $9.57 \pm 18.61$ & $171.13 \pm 68.18$ \\
\hline $\mathrm{C} 4$ & $\begin{array}{l}\text { OEP }\left(0.5 \mathrm{~mL} \mathrm{~kg}^{-1} \text {, p.o., daily for } 10 \text { days }\right)+ \\
\text { CP }\left(30 \mathrm{mg} \mathrm{kg}^{-1} \text {, i.p., } 48 \text { and } 24 \mathrm{~h} \text { before sac- }\right. \\
\text { rifice })\end{array}$ & $21 \pm 10.40$ & $41.5 \pm 24.57$ & $14.88 \pm 9.73$ & $14.5 \pm 15.67$ & $7.5 \pm 9.75$ & $144.75 \pm 57.22^{\mathrm{b}}$ \\
\hline $\mathrm{C} 5$ & BLM ( $25 \mathrm{mg} \mathrm{kg}^{-1}$, i.p., $24 \mathrm{~h}$ before sacrifice) & $4.29 \pm 2.81$ & $36.5 \pm 12.99$ & $47 \pm 13.53$ & $13.75 \pm 10.36$ & $2.13 \pm 3.44$ & $180.25 \pm 39.96^{\mathrm{c}}$ \\
\hline C6 & $\begin{array}{l}\text { OEP }\left(0.5 \mathrm{~mL} \mathrm{~kg}^{-1}, \text { p.o., daily for } 10 \text { days }\right)+ \\
\operatorname{BLM}\left(25 \mathrm{mg} \mathrm{kg}^{-1} \text {, i.p., } 24 \mathrm{~h} \text { before sacrifice }\right)\end{array}$ & $8.38 \pm 6.74$ & $39 \pm 13.42$ & $41.5 \pm 15.48$ & $9.25 \pm 6.78$ & $2.0 \pm 2.98$ & $157.75 \pm 27.03^{\mathrm{d}}$ \\
\hline $\mathrm{C} 7$ & $\operatorname{AEP}\left(1 \mathrm{~mL} \mathrm{~kg}^{-1}\right.$, p.o., daily for 10 days $)$ & $9.75 \pm 7.06$ & $39.88 \pm 13.91$ & $29.88 \pm 14.09$ & $12.38 \pm 14.94$ & $8.13 \pm 7.07$ & $169.25 \pm 33.13$ \\
\hline $\mathrm{C} 8$ & $\begin{array}{l}\text { AEP }\left(1 \mathrm{~mL} \mathrm{~kg}^{-1} \text {, p.o., daily for } 10 \text { days }\right) \\
+ \text { CP }\left(30 \mathrm{mg} \mathrm{kg}^{-1} \text {, i.p., } 48 \text { and } 24 \mathrm{~h} \text { before }\right. \\
\text { sacrifice })\end{array}$ & $2.0 \pm 1.85$ & $68 \pm 10.81$ & $21.88 \pm 9.49$ & $5.13 \pm 3.76$ & $3.0 \pm 3.38$ & $139.13 \pm 16.57^{\mathrm{e}}$ \\
\hline C9 & $\begin{array}{l}\text { AEP }\left(1 \mathrm{~mL} \mathrm{~kg}^{-1} \text {, p.o., daily for } 10 \text { days }\right)+ \\
\text { BLM }\left(25 \mathrm{mg} \mathrm{kg}^{-1} \text {, i.p., } 24 \mathrm{~h} \text { before sacrifice }\right)\end{array}$ & $6.13 \pm 6.10$ & $62.5 \pm 16.48$ & $27.63 \pm 13.64$ & $1.63 \pm 2.26$ & $2.13 \pm 3.09$ & $131.13 \pm 14.29^{\mathrm{f}, \mathrm{g}}$ \\
\hline
\end{tabular}

${ }^{\mathrm{a}} \mathrm{p}=0.0008$ compared to $\mathrm{C} 1 .{ }^{\mathrm{b}} \mathrm{p}=0.0008$ compared to $\mathrm{C} 2 .{ }^{\mathrm{c}} \mathrm{p}=0.0016$ compared to $\mathrm{C} 1 .{ }^{\mathrm{d}} \mathrm{p}=0.0134$ compared to $\mathrm{C} 1{ }^{\mathrm{e}} \mathrm{p}=0.0008$ compared to $\mathrm{C} 2$. ${ }_{\mathrm{f}}^{\mathrm{p}}=0.0273$ compared to C6. ${ }^{\mathrm{g}} \mathrm{p}=0.0023$ compared to C5.

was prepared by dissolving TBA (Merck; final concentration $29 \mathrm{mmol} / \mathrm{L})$ in acetic acid $(8.75 \mathrm{~mol} / \mathrm{L}$; Merck). The stock standard solution of MDA was prepared by dissolving $480 \mu \mathrm{L}$ of 1,1,3,3-tetraethoxypropane (Sigma) in $100 \mathrm{~mL}$ of ethanol (Merck). Immediately before use, the solution was diluted in Milli-Q water to yield a working solution of $10 \mu \mathrm{mol} / \mathrm{L}$. The other reagents for the assay were purchased from Sigma (n-butanol) or Merck (EDTA, glutathione-GSH, and hydrochloric acid). Working aqueous solutions of EDTA $(67.3 \mathrm{mmol} / \mathrm{L})$ and $\mathrm{GSH}(32.5 \mathrm{mmol} / \mathrm{L})$ were prepared freshly immediately before use (to avoid GSH oxidation).

Blood was collected by cardiac puncture using na insulin syringe containing EDTA as anticoagulant. After centrifugation $\left(1500 \times \mathrm{g}, 10 \mathrm{~min}, 4{ }^{\circ} \mathrm{C}\right)$, the plasma was carefully removed and EDTA and GSH were added to final concentrations of $1.34 \mathrm{mmol} / \mathrm{L}$ and $0.65 \mathrm{mmol} / \mathrm{L}$, respectively. The samples were then quickly frozen in liquid nitrogen and stored at $-80{ }^{\circ} \mathrm{C}$ until used.

For the TBARS test, $50 \mu \mathrm{L}$ of plasma or an equal volume of MDA working standard was added to $10 \mathrm{~mL}$ glass tubes containing $1 \mathrm{~mL}$ of Milli-Q water, followed by $1 \mathrm{~mL}$ of solution containing TBA $(29 \mathrm{mmol} / \mathrm{L})$ in acetic acid $(\mathrm{pH}$ of the reaction mixture, 2.4-2.6), mixing, and heating in a water bath for $1 \mathrm{~h}$ at $95^{\circ}-100^{\circ} \mathrm{C}$. The samples were then cooled and $25 \mu \mathrm{L}$ of $5 \mathrm{~mol} / \mathrm{L} \mathrm{HC1}$ was added (final $\mathrm{pH}$ 1.6-1.7), followed by extraction with $3.0 \mathrm{~mL}$ of n-butanol and vortex mixing for $30 \mathrm{~s}$. The butanol phase was separated by centrifugation $(1500 \mathrm{x} \mathrm{g}, 10 \mathrm{~min})$ and its fluorescence was measured with a Jasco FP-777 spectrofluoro- meter (excitation: $525 \mathrm{~nm}$, emission: $547 \mathrm{~nm}$ ). A standard curve was prepared with MBA $(0-0.15 \mu \mathrm{mol} / \mathrm{L})$.

\section{Statistical analysis}

The results were expressed as the mean \pm SD. Statistical comparisons were done by using the Mann-Whitney U-test, with $\mathrm{p}<0.05$ indicating significance.

\section{Results}

\section{Anticlastogenic and antigenotoxic assays}

\section{Micronucleus (MN) test}

Neither of the doses of OEP $\left(1 \mathrm{~mL} \mathrm{~kg}^{-1}\right.$ - group M3 or $0.5 \mathrm{~mL} \mathrm{~kg}^{-1}$ - group M8) had any clastogenic effect on mouse bone marrow cells when compared with the control group (M1) (Table 1). However, the cellular proliferation index in mouse bone marrow cells, expressed as the percentage of PCE, increased in groups M3 and M8 ( $p=0.0117$ and $p=0.0460$, respectively). There was no significant difference in the frequencies of MN-PCE $(p=0.5780)$, MN-NCE $(p=0.7004)$ and the cellular proliferation index $(\mathrm{p}=0.9163)$ between groups M3 and M8. Cyclophosphamide (30 $\mathrm{mg} \mathrm{kg}^{-1}$, group M2) increased the frequency of MN-PCE, indicating this drugs clastogenic effect. Concomitant treatment with OEP $\left(0.5 \mathrm{~mL} \mathrm{~kg}^{-1}\right.$, group M9) did not significantly affect the percentage of PCE compared to M2. In contrast, concomitant treatment with OEP ( $1 \mathrm{~mL} \mathrm{~kg}^{-1}$, group M4) increased the frequency of MN-PCE to a greater extent than seen with CP or OEP alone $(\mathrm{p}=0.0309)$. 
Bleomycin (50 mg kg-1; group M5) was clearly cytotoxic and caused cellular lysis (no erythroblasts were seen). At a dose of $25 \mathrm{mg} \mathrm{kg}^{-1}$, bleomycin did not significantly alter the frequency of MN-PCE (group M7 vs. M1), but caused significant induction at $10 \mathrm{mg} \mathrm{kg}^{-1}$ (group M11), indicating a clastogenic effect on these cells. Comparison of groups M5 and M6 showed that OEP $\left(1 \mathrm{~mL} \mathrm{~kg}^{-1}\right)$ clearly protected bone marrow cells against bleomycin $(50 \mathrm{mg}$ $\mathrm{kg}^{-1}$ )-induced lysis $(\mathrm{p}=0.0003$ for MN-PCE, $\mathrm{p}=0.0011$ for $\mathrm{MN}-\mathrm{NCE}$ and $\mathrm{p}=0.0003$ for $\% \mathrm{PCE})$. On the other hand, the combination of OEP $\left(0.5 \mathrm{~mL} \mathrm{~kg}^{-1}\right)+$ bleomycin $(25 \mathrm{mg}$ $\mathrm{kg}^{-1}$ ) (group M10) did not significantly affect MN-PCE, but reduced MN-NCE when compared with group M7 $(\mathrm{p}=0.0332)$. Although the combination OEP $\left(0.5 \mathrm{~mL} \mathrm{~kg}^{-1}\right)$ + bleomycin (10 $\left.\mathrm{mg} \mathrm{kg}^{-1}\right)$ (group M12) did not significantly decrease MN-PCE when compared with group M11, it significantly increased $(p=0.0357)$ the $\%$ PCE relative to the latter group.

\section{Single-cell gel electrophoresis assay (SCGE - comet assay)}

Table 2 shows the results of the comet assay in peripheral blood leukocytes of mice treated with $\mathrm{OEP}(0.5 \mathrm{~mL}$ $\mathrm{kg}^{-1}$; group C3) and AEP (1 mL kg-1; group C7). Neither OEP (C3) nor AEP (C7) significantly affected the DNA damage (DD) compared to group C1 (negative control), indicating that the extracts had no genotoxic effect in these cells. Likewise, there was no significant difference between $\mathrm{C} 3$ and C7. CP $\left(30 \mathrm{mg} \mathrm{kg}^{-1} ; \mathrm{C} 2\right)$ and BLM $\left(25 \mathrm{mg} \mathrm{kg}^{-1}\right.$; C5) were significantly genotoxic when compared with $\mathrm{C} 1$ $(p=0.0008$ and $p=0.0016$, respectively). However, there was no significant difference between $\mathrm{C} 1$ and $\mathrm{C} 4$ (OEP $0.5 \mathrm{~mL} \mathrm{~kg}^{-1}+$ CP $\left.30 \mathrm{mg} \mathrm{kg}^{-1}\right)$ or C8 (AEP $1 \mathrm{~mL} \mathrm{~kg}^{-1}+\mathrm{CP}$ $30 \mathrm{mg} \mathrm{kg}^{-1}$ ), indicating that at the doses tested OEP and AEP were efficient in protecting cells against the genotoxicity of $\mathrm{CP}\left(30 \mathrm{mg} \mathrm{kg}^{-1}\right)$. Comparison of $\mathrm{C} 2$ with $\mathrm{C} 4$ and C8 corroborated this protective effect ( $p=0.0008$ in both cases), although there were no significant differences between $\mathrm{C} 4$ and $\mathrm{C} 8$. When group $\mathrm{C} 1$ was compared with $\mathrm{C} 6$ (OEP $0.5 \mathrm{~mL} \mathrm{~kg}^{-1}+$ BLM $25 \mathrm{mg} \mathrm{kg}^{-1}$ ) or C9 (AEP $1 \mathrm{~mL}$ $\mathrm{kg}^{-1}+$ BLM $25 \mathrm{mg} \mathrm{kg}^{-1}$ ), only AEP showed significant protection $(\mathrm{p}=0.0134)$. Similar protection was seen in the comparison of $\mathrm{C} 6$ with $\mathrm{C} 9(\mathrm{p}=0.0273)$ and $\mathrm{C} 5$ with $\mathrm{C} 9$ $(\mathrm{p}=0.0023)$, indicating that AEP provided greater protection than OEP against bleomycin $\left(25 \mathrm{mg} \mathrm{kg}^{-1}\right)$-induced DNA damage; there was no difference between C5 (BLM $25 \mathrm{mg} \mathrm{kg}^{-1}$ ) and C6.

\section{Antioxidant activity (TBARS assay)}

There was no significant difference in the TBARS levels of female (group T1) and male (group T2) mice (Table 3). There were also no significant differences between $\mathrm{T} 1$ and T3, T3 and T5 or T4 and T6. However, mice treated with AEP showed significant lipid peroxidation $(\mathrm{p}=0.0248$ for $\mathrm{T} 1 v s$. T5, and $\mathrm{p}=0.0001$ for $\mathrm{T} 2$ vs. T6), indicating that AEP $\left(1 \mathrm{~mL} \mathrm{~kg}^{-1}\right)$ enhanced oxidative stress in both sexes, especially in males. A similar result was observed between control males and males treated with OEP $\left(0.5 \mathrm{~mL} \mathrm{~kg}^{-1}\right)(\mathrm{T} 2$ vs. T4, $\mathrm{p}=0.00002$ ). Thus, at the doses used, neither of the extracts protected males against lipid peroxidation.

\section{Discussion}

Micronuclei in interphase cells result from chromosomal breaks or chromosomal lagging (Schmid, 1975; Natarajan and Obe, 1982; FDA, 2000), and DNA damage to eukaryotic organisms or individual cells is frequently assessed with the comet assay (Henderson et al., 1998; Garcia et al., 2004). In the present study, the MN test and comet assay showed that OEP $\left(0.5 \mathrm{~mL} \mathrm{~kg}^{-1}\right.$ or $\left.1 \mathrm{~mL} \mathrm{~kg}^{-1}\right)$ had no clastogenic or genotoxic effect on mouse bone marrow cells or peripheral blood lymphocytes, a finding that corroborated the $\mathrm{MN}$ test results reported by Khouri et al. (2007).

Bleomycin sulphate (BLM), a radiomimetic glycopeptide routinely used in cancer chemotherapy, produces $\mathrm{MN}$ in human, rat and mouse cells, mainly through oxidative damage to DNA (Erexson et al., 1995). Bleomycinmediated DNA degradation requires the presence of a redox-active metal ion such as $\mathrm{Fe}^{2+}$ or $\mathrm{Cu}^{2+}$ as well as molecular oxygen, to produce reactive oxygen species (ROS) that are toxic and mutagenic in a variety of biological models in vitro and in vivo (Hoffmann et al., 1993; Anderson et al., 1995; Erexson et al., 1995; Hecht, 2000).

Table 3 - Lipid peroxidation (TBARS levels) in plasma of Swiss white mice treated orally an organic (OEP, $\left.0.5 \mathrm{~mL} \mathrm{~kg}^{-1}\right)$ or aqueous $\left(\mathrm{AEP}, 1 \mathrm{~mL} \mathrm{~kg}{ }^{-1}\right)$ extract of pequi (Caryocar brasiliense) fruit pulp.

\begin{tabular}{llcc}
\hline Group & Treatment & Fluorescence $(\operatorname{mean} \pm \mathrm{SD})$ & $\mathrm{MDA}(\mu \mathrm{mol} / \mathrm{L})(\mathrm{mean} \pm \mathrm{SD})$ \\
\hline T1 & Female control group (filtered water) & $311.16 \pm 41.26$ & $0.023 \pm 0.003$ \\
T2 & Male control group (filtered water) & $307.9 \pm 18.17$ & $0.023 \pm 0.001$ \\
T3 & Females treated with OEP $\left(0.5 \mathrm{~mL} \mathrm{~kg}^{-1}\right.$, p.o., daily for 10 days $)$ & $337.31 \pm 39.59$ & $0.025 \pm 0.003$ \\
T4 & Males treated with OEP $\left(0.5 \mathrm{~mL} \mathrm{~kg}^{-1}\right.$, p.o., daily for 10 days) & $421.36 \pm 46.29^{\mathrm{a}}$ & $0.031 \pm 0.003$ \\
T5 & Females treated with AEP $\left(1 \mathrm{~mL} \mathrm{~kg}^{-1}\right.$, p.o., daily for 10 days $)$ & $345.0 \pm 28.42^{\mathrm{b}}$ & $0.026 \pm 0.002$ \\
T6 & Males treated with AEP $\left(1 \mathrm{~mL} \mathrm{~kg}^{-1}\right.$, p.o., daily for 10 days $)$ & $392.2 \pm 39.95^{\mathrm{c}}$ & $0.029 \pm 0.003$ \\
\hline
\end{tabular}

${ }^{\mathrm{a}} \mathrm{p}=0.00002$ compared to T2. ${ }^{\mathrm{b}} \mathrm{p}=0.0248$ compared to T1. ${ }^{\mathrm{c}} \mathrm{p}=0.0001$ compared to T2. 
As shown here, the prior administration of OEP $\left(1 \mathrm{~mL} \mathrm{~kg}^{-1}\right.$ ) clearly protected mouse bone marrow cells against lysis induced by BLM (50 $\left.\mathrm{mg} \mathrm{kg}^{-1}\right)$; a lower dose of OEP $\left(0.5 \mathrm{~mL} \mathrm{~kg}^{-1}\right)$ also protected against the natural clastogenic effects, although the decrease in MN-NCE was not significant. Hence, both of the OEP doses used offered some protection against the clastogenicity of BLM. This finding was corroborated by the comet assay. AEP $\left(1 \mathrm{~mL} \mathrm{~kg}^{-1}\right)$ offered greater protection against BLM (25 mg kg-1)-induced DNA damage than OEP $\left(0.5 \mathrm{~mL} \mathrm{~kg}^{-1}\right)$; the reduction in DNA damage by the latter was not significant.

Since the cytotoxicity of BLM involves the production of ROS (Hoffmann et al., 1993; Anderson et al., 1995; Erexson et al., 1995; Hecht, 2000), our results suggest that the protection against BLM-induced oxidative damage to DNA was mediated by antioxidant components in the $C$. brasiliense extracts. Indeed, previous studies have indicated that compounds with antioxidant activities may modulate BLM-induced genotoxicity (Povirk and Austin, 1991; Povirk, 1996; Khouri et al., 2007). The results of the comet assay corroborated those of the MN test and showed that the ability of the two extracts to protect against BLM was limited by the dose of extract used. The greater protection seen with AEP probably reflected its higher content of antioxidants compared to that of OEP at the doses used.

Chemotherapy with CP can cause secondary tumors in humans by activating hepatic mixed function oxidases. Phosphoramide mustard, the major antineoplastic metabolite of CP, is an alkylating agent that induces a variety of changes in DNA (IARC, 1981; Krishna et al., 1987) through its ability to form labile covalent DNA adducts and cross-linkages (Anderson et al., 1995).

Compounds with antioxidant properties, such as vitamin $C$ (present in AEP) and $\beta$-carotene (present in OEP) can have antioxidant and oxidant effects that are dosedependent (Antunes and Takahashi, 1999; Paolini et al., 2003). This two-sided or Janus effect reflects the dual nature of certain chemical substances such as antioxidants and drugs used to treat cancer. As shown here, OEP had a Janus effect: at $0.5 \mathrm{~mL} \mathrm{~kg}^{-1} \mathrm{OEP}$ effectively protected cells against the genotoxicity of CP (comet assay) without significantly protecting against chromosomal aberrations (MN test) whereas at $1 \mathrm{~mL} \mathrm{~kg}^{-1} \mathrm{OEP}$ increased the frequency of $\mathrm{MN}$ in the presence of CP $\left(30 \mathrm{mg} \mathrm{kg}^{-1}\right)$. Similar results were reported by Khouri et al. (2007) who studied the combination of AEP $\left(1 \mathrm{~mL} \mathrm{~kg}^{-1}\right)$ plus $\mathrm{CP}\left(33 \mathrm{mg} \mathrm{kg}^{-1}\right.$ or $66 \mathrm{mg} \mathrm{kg}^{-1}$ ).

With the treatment schedule used here, it was not possible to determine whether the protection offered by the extracts was related to a reduction in the efficacy of BLM or $\mathrm{CP}$ (by affecting the pharmacokinetics of these compounds), or to a direct effect on the cells themselves. However, previous studies have shown that natural antioxidants can prevent the oxidation of biomolecules, including DNA, without decreasing the effectiveness of chemotherapeutic compounds. According to Liu et al. (2003) and Berger (2005), an antioxidant dietary supplement can reduce the level of oxidative damage to DNA and protect normal cells against the adverse side-effects of some chemotherapeutic agents. Nutritional therapy with antioxidants concomitant with chemotherapy reduces the frequency and severity of adverse effects associated with many drugs in cancer patients, thereby allowing the treatment to be continued (the toxicity of anti-cancer drugs is a frequent limitation to their extended use) (Borek, 2004). As shown here, OEP and AEP protected against oxidative DNA damage caused by BLM or CP, which agrees with the ability of antioxidants to inhibit chemical mutagenesis in vivo and with studies showing that plant extracts contain antioxidants that can protect DNA against damage by ROS (Cano et al., 2003; Lee et al., 2003; Owen et al., 2003; Khouri et al., 2007). However, our results indicate that this protection is related to the dose of extract used.

Organisms are constantly exposed to the action of ROS and the presence of antioxidants in the diet can protect against oxidative processes (Ferreira and Matsubara, 1997; Degáspari and Waszczynskyj, 2004). In contrast, the use of nutritional supplements with antioxidant properties is controversial. Antunes and Takahashi (1999) showed that vitamin $C$ had antimutagenic activity only at certain concentrations; at high concentrations this compound did not protect against mutations but was cytotoxic to lymphocytes. Paolini et al. (2003) reported that $\beta$-carotene prevented oxidative lesions in DNA but stimulated cytochrome P450 enzymes, leading to the bioactivation of pro-carcinogenic agents such as those found in cigarette smoke. In agreement with these studies, the OEP of pequi fruit may contain high concentrations of many antioxidant compounds capable of exerting a pro-oxidative effect and increasing DNA lesions when combined with CP or BLM.

The TBARS assay is a simple, reliable and reproducible fluorometric method for assessing lipid peroxidation in serum, and is based on the reaction between malondialdehyde (MDA), a byproduct of lipid peroxidation, and thiobarbituric acid. Oxidative attack of cellular components by ROS is a common phenomenon in the pathogenesis of several human diseases, including cardiovascular diseases (e.g., atherosclerosis), diabetes, various liver disorders, and inflammatory rheumatic diseases. For this reason, there is considerable interest in the quantification of MDA in body fluids or cells (Wasowicz et al., 1993; Jentzsch et al., 1996). The TBARS results obtained here indicate that high doses of plant extracts rich in antioxidant compounds can produce unexpected effects. Since the 1980s, there has been a considerable increase in the search for natural antioxidants that can be included in the diet as a substitute for synthetic antioxidants (Degáspari and Waszczynskyj, 2004). The TBARS results obtained here in female mice suggest that the antioxidant properties of OEP 
make this product a potentially useful dietary supplement, in addition to its other nutritional properties.

The anticlastogenic and antigenotoxic activities of OEP seen in this study were attributable to its content of antioxidants. However, the comet assay and MN test results obtained here and by Khouri et al. (2007) indicate that, at the doses used, AEP was more effective than OEP in protecting DNA against damage by clastogenic agents. However, the ability of OEP and AEP to protect against BLMor CP-induced oxidative damage to DNA depended on the dose of extract used.

\section{Acknowledgments}

This work was supported by the University of Brasilia and Scientific and Technological Enterprises Foundation (FINATEC).

\section{References}

Almeida SP de (1998) Frutas nativas do cerrado: Caracterização físico-química e fonte potencial de nutrientes. In: Sano SM and Almeida SP de (eds) Cerrado: Ambiente e Flora. EMBRAPA-CPAC, Planaltina, pp 247-285.

Almeida SP de and Silva JA (1994) Pequi e Buriti - Importância Alimentar para a População dos Cerrados. EMBRAPACPAC, Planaltina, 38 pp.

Anderson D, Bishop JB, Garner RC, Ostrosky-Wegman P and Selby PB (1995) Cyclophosphamide: Review of its mutagenicity for an assessment of potential germ cell risks. Mut Res 330:115-181.

Antunes LM and Takahashi CS (1999) Protection and induction of chromosomal damage by vitamin $\mathrm{C}$ in human lymphocytes cultures. Teratog Carcinog Mutagen 19:53-59.

Azevedo-Meleiro CH and Rodriguez-Amaya DB (2004) Confirmation of the identity of the carotenoids of tropical fruits by HPLC-DAD and HPLC-MS. JFCA 17:385-396.

Barbosa RCMV and Amante ER (2005) Farinha da casca de pequi (Caryocar brasiliense). http://www.ufpel.tche.br/sbfruti/ anais_xvii_cbf/tecnologia_de_alimentos/015.htm (October 29, 2006)

Berger MM (2005) Can oxidative damage be treated nutritionally? Clin Nutr 24:172-183.

Boletim Informativo UFMG n. 1511 (2005) Os Frutos da Genética. http://www.ufmg.br/boletim/bol1511/sexta.shtml (May 31, 2007).

Borek C (2004) Dietary antioxidants and human cancer. Integ Cancer Ther 3:333-341.

Cano A, Acosta M and Arnao MB (2003) Hydrophilic and lipophilic antioxidant activity changes during on-vine ripening of tomatoes (Lycopersicon esculentum Mill). Post Biol Technol 28:59-65.

Degáspari CH and Waszczynskyj N (2004) Propriedades antioxidantes de compostos fenólicos. Vis Acad 5:33-40.

Dusinská M, Kasimirová A, Barancoková M, Beno M, Smotkova B, Horská A, Wsolova JL and Collins AR (2003) Nutritional supplementation with antioxidants decreases chromosomal damage in humans. Mutagenesis 18:371-376.

Erexson GL, Bryant MF, Kwanyuen P and Kligerman AD (1995) Bleomycin sulfate-induced micronuclei in human, rat and mouse peripheral blood lymphocytes. Environ $\mathrm{Mol} \mathrm{Mu}-$ tagen 25:31-36.

FDA (U.S. Food and Drug Administration) (2000) Toxicological Principles for the Safety Assessment of Food Ingredients. Redbook 2000: IV.C.1.d. Mammalian Erythrocyte Micronucleus Test. http://www.cfsan.fda.gov/ redbook/ redivc1d.html (June 16, 2007).

Ferreira ALA and Matsubara LS (1997) Radicais livres: Conceitos, doenças relacionadas, sistema de defesa e estresse oxidativo. Rev Assoc Med Bras 43:61-68.

Garcia O, Mandina T, Lamadrid AI, Diaz A, Remigio A, Gonzalez Y, Piloto J, Gonzalez JE and Alvarez A (2004) Sensitivity and variability of visual scoring in the comet assay: Results of an inter-laboratory scoring exercise with the use of silver staining. Mut Res 556:25-34.

Hecht SM (2000) Bleomycin: New perspectives on the mechanism of action. J Nat Prod 63:158-168.

Henderson L, Wolfreys A, Fedyk J, Bourner C and Windebank S (1998) The ability of the comet assay to discriminate between genotoxins and cytotoxins. Mutagenesis 13:89-94.

Hoffmann GR, Colyer SP and Littlefield G (1993) Induction of micronuclei by bleomycin in $\mathrm{G}_{0}$ human lymphocytes: I. Dose-response and distribution. Environ Mol Mutagen 21:130-135.

IARC (1981) Some antineoplastic and immunosuppressive agents. In: Monographs on the Evaluation of the Carcinogenic Risk of Chemicals to Humans, v. 26. International Agency for Research on Cancer, Lyon, pp 165-202.

Jaloszynski P, Kujawsk M, Czub-Swierczek M, Markowska J, Szyfter K (1997) Bleomycin-induced DNA damage and it's removal in lymphocytes of breast cancer patients studied by comet assay. Mutat Res 385:223-233.

Jentzsch AM, Bachmann H, Furst P and Biesalski HK (1996) Improved human analysis of malondialdehyde in body fluids. Free Radic Biol Med 20:251-256.

Khouri J, Resck IS, Poças-Fonseca M, Souza TMM, Pereira LO, Oliveira ABB and Grisolia CK (2007) Anticlastogenic potential and antioxidant effects of the aqueous extract of pulp from "pequi" (Caryocar brasiliense Camb). Gen Mol Biol 30:442-448.

Kong Q and Lillehei KO (1998) Antioxidant inhibitors for cancer therapy. Med Hypot 51:405-409.

Krishna G, Nath J, Peterson M and Ong T (1987) Cyclophosphamide-induced cytogenetic effects in mouse bone marrow and spleen cells in vivo and in vivo/in vitro assays. Teratog Carcinog Mutagen 7:183-195.

Lee PJ, Min BS, Na RB, Na MK, Lee SM, Lee HK, Kim JG, Bae KH and Kang SS (2003) Stilbenes from the roots of Pleuropterus ciliinervis and their antioxidant activities. Phytochemistry 64:759-763.

Liu X, Zhao J and Zheng R (2003) DNA damage of tumorassociated lymphocytes and total antioxidant capacity in cancerous patients. Mutat Res 539:1-8.

Martino-Roth MG, Viégas J and Roth DM (2003) Occupational genotoxicity risk evaluation though the comet assay and the micronucleus test. Genet Mol Res 2:410-417.

Natarajan AT and Obe G (1982) Mutagenicity testing with cultured mammalian cells: Cytogenetic assays. In: John A Heddle (ed) Mutagenicity - New Horizons in Genetic Toxicology. Academic Press, New York, pp 171-212. 
Oliveira MNS, Gusmão EL, Nascimento OS, Simões MOM, Ribeiro LM and Dias BAS (2006) Estádio de maturação dos frutos e fatores relacionados aos aspectos nutritivos e de textura da polpa de pequi (Caryocar brasiliense Camb.). Rev Bras Frutic 28:380-386 (Abstract in English).

Owen RW, Haubner R, Mier W, Giacosa A, Hull WE, Spiegelhalder B and Bartsch H (2003) Isolation, structure elucidation and antioxidant potential of the major phenolic flavonoid compounds in brined olive drupes. Food Chem Toxicol 41:703-717.

Paolini M, Abdel-Rahman SZ, Sapone A, Pedulli GF, Perocco P, Cantelli-Forti G and Legator MS (2003) $\beta$-carotene: A cancer chemopreventive agent or a co-carcinogen? Mutat Res 543:195-200.

Povirk LF (1996) DNA damage and mutagenesis by radiomimetic DNA-cleaving agents: Bleomycin, neocarzinostatin and other enediynes. Mutat Res 355:71-89.

Povirk LF and Austin MJF (1991) Genotoxicity of bleomycin. Mutat Res 257:127-143.

Ramos MIL, Umaki MCS, Hiane PA and Ramos-Filho MM (2001) Efeito do cozimento convencional sobre os carotenóides pró-vitamínicos "A" da polpa de piqui (Caryocar brasiliense Camb.). B CEPPA 19:23-32.

Santos BR, Paiva R, Dombroski JLD, Martinotto C, Nogueira RC and Silva AAN (2005) Pequizeiro (Caryocar brasiliense Camb.): Uma espécie promissora do cerrado brasileiro. UFLA.
http://www.editora.ufla.br/BolTecnico/pdf/bol_64.pdf (October/2006).

Santos HS and Cruz WMS (2001) A terapia nutricional com vitaminas antioxidantes e o tratamento quimioterápico oncológico. Rev Bras Cancerol 47:303-308 (Abstract in English).

Schmid W (1975) The micronucleus test. Mutat Res 31:9-15.

Sies H (1993) Strategies of antioxidant defense. Eur J Biochem 215:213-219.

Singh NP, McCoy MT, Tice RR and Scheneider EL (1988) A simple technique for quantitation of low levels of DNA damage in individual cells. Exp Cell Res 175:184-191.

Tice RR (1995) The single cell gel/comet assay: A microgel electrophoretic technique for the detection of DNA damage and repair in individual cells. In: Phillips DH and Venitt S (eds) Environmental Mutagenesis. Bios Scientific Publishers, Oxford, pp 315-339.

Tseng CF, Lin CC, Huang HY, Liu HC and Mao SJT (2004) Antioxidant role of human haptoglobin. Proteomics 4:22212228.

Wasowicz W, Nève J and Peretz A (1993) Optimized steps in fluorometric determination of thiobarbituric acid-reactive substances in serum: Importance of extraction $\mathrm{pH}$ and influence of sample preservation and storage. Clin Chem 39:2522-2526.

Associate Editor: Catarina S. Takahashi

License information: This is an open-access article distributed under the terms of the Creative Commons Attribution License, which permits unrestricted use, distribution, and reproduction in any medium, provided the original work is properly cited. 